\title{
Penentuan Rute dan Jumlah Kendaraan pada Kasus School Bus Routing Problem:
} Penerapan Algoritma Record-to-Record Travel

\section{Determining Route and Number of Vehicle for School Bus Routing Problem Case: An Application of Record-to-record Travel Algorithm}

\author{
Fadillah Ramadhan*, Arif Imran \\ Program Studi Teknik Industri, Fakultas Teknologi Industri, Institut Teknologi Nasional
}

ARTICLE INFO

Riwayat artikel:

Diterima 24-05-2018

Diperbaiki 18-08-18

Disetujui 21-09-2018

Kata Kunci:

Distribusi, heuristic, record-

to-record, SBRP,

transportasi, VRP

\section{A B S T R A K}

Program bus sekolah gratis merupakan salah satu program yang sedang dikembangkan untuk menunjang kemajuan pendidikan. Penentuan rute dan jumlah bus sekolah yang dapat meminimumkan biaya perjalanan dan pengadaan kendaran merupakan aspek penting dalam menerapkan program bus sekolah. Penelitian ini membangun algoritma dan program perangkat lunak untuk model school bus routing problem (SBRP) yang dapat meminimisasi biaya perjalanan dan biaya investasi jumlah kendaraan bus. Algoritma record-torecord travel digunakan untuk mendapatkan solusi yang baik dengan waktu komputasi yang relatif cepat pada program perangkat lunak yang dibangun. Karakteristik model SBRP pada penelitian ini, bus memiliki kapasitas terbatas dan homogen, titik awal bus berada di depot, lalu mendatangi beberapa halte dimana setiap halte memiliki jumlah penumpang yang deterministik. Setelah mendatangi halte terakhir, bus akan mendatangi halte dengan arah kebalikannya yang diakhiri di titik awal (depot). Program bus sekolah gratis di Kota Bandung dijadikan objek penelitian mengingat program tersebut sedang diterapkan dan dievaluasi untuk meningkatkan efektivitas penggunaannya. Hasil yang didapatkan pada penelitian ini, model SBRP dan algoritma record-to-record travel yang dibangun dan diujikan pada kasus bus sekolah di Kota Bandung memperlihatkan solusi yang layak dan baik dengan total biaya yang minimum. Proses pengelompokkan bus per wilayah Kota Bandung dapat dihasilkan dan menunjukkan biaya perjalanan dan biaya investasi pengadaan kendaraan bus yang minimum. Selain itu, algoritma ini terbukti dapat menyelesaikan permasalahan SBRP dengan waktu komputasi yang cepat, yaitu dibawah 10 detik.
Keywords:

Distribution, heuristic, record-to-record, SBRP, transportation, VRP

\section{A B S T R ACT}

The free school bus program is one of program developed to support the improvement of education. Determination of the route and the number of school buses that can minimize travel and vehicle procurement costs are an important aspect in implementing the school bus program. This research builds an algorithm and software program for school bus routing problem (SBRP) model that can minimize the travel and investment cost of the bus. The record-to-record travel algorithm is used for obtaining a good solution with a reasonable time on the software program that's being built. Characteristics of the SBRP model in this study, the bus vehicle has a limited and homogeneous capacity, the starting point of the bus is in the depot, and then the bus travel to each bus stop where each stop has a deterministic number of passengers. After arriving at the last bus stop, the bus will come to the bus stop in the opposite direction that ends at the starting point of the depot. The free bus program in Bandung City is used as an object of research. The results obtained in this study, the SBRP model and the record-to-record travel algorithm that was built and tested in the case of school buses in Bandung City are feasible and the result is good. The process of buses grouping for each region of Bandung City can be generated with the minimum operational costs. In addition, this algorithm is proven to solve the problem of SBRP with fast completion time, which is less than 10 seconds. 


\section{Pendahuluan}

Penyediaan sarana transportasi untuk kegiatan sekolah seperti bus sekolah merupakan salah satu sarana penunjang yang sangat penting dalam mambangun pendidikan di suatu daerah. Di berbagai daerah, program bus sekolah yang aman, nyaman, murah, bahkan gratis merupakan salah satu program yang sedang diterapkan dan dikembangkan untuk menunjang kemajuan pendidikan. Salah satu aspek penting dalam menerapkan program bus sekolah tersebut adalah penentuan rute dan jumlah bus yang dapat meminimumkan biaya operasional. Dengan biaya operasional yang minimum, maka program bus sekolah dapat diimplementasi dalam jangka waktu yang lama dan memungkinkan adanya penetapan biaya yang gratis bagi setiap pemakainya.

Penentuan rute yang minimum dalam kegiatan transportasi merupakan bahasan penting dalam lingkup vehicle routing problem (VRP). VRP merupakan permasalahan rute yang berkaitan dengan perancangan rute transportasi dalam pelayanan pendistribusian atau pengambilan produk dari titik asal ke beberapa titik tujuan $[1$, 2]. Pada kasus bus sekolah, fokus pelayanan berada pada manusia yang dianalogikan sebagai objek pendistribusian yang biasa dikenal sebagai school bus routing problem (SBRP). SBRP merupakan varian dari VRP yang pada prinsipnya terfokus pada aspek persiapan data, penentuan tempat berhenti bus, penentuan rute bus, waktu pulang dan pergi bus beserta penjadwalan pergantian rute [3].

Terdapat beberapa peneliti yang telah melakukan penelitian terkait dengan SBRP $[4,5,6]$. Li dan $\mathrm{Fu}$ [7] membahas terkait SBRP dengan meggunakan multi-objective combinatorial optimization. Multi-objective yang dimaksud adalah peneltian yang dilakukan untuk menyelesaikan lebih dari satu fungsi tujuan, yaitu untuk meminimumkan jumlah bus yang dibutuhkan dan jumlah waktu perjalanan dari permasalahan SBRP dengan menggunakan algoritma heuristic.

Riera-Ledesma dan Salazar-Gonzalez [8] memecahkan permasalahan SBRP dengan menggunakan multiple vehicle traveling purchaser. Penelitian tersebut mengkombinasikan penyeleksian tempat berhenti bus dan penentuan rute bus dengan algoritma branch-and-cut.

Beberapa penelitian SBRP yang diimplementasi langsung pada studi kasus dilakukan oleh Huo dkk. [9] yang meneliti SBRP dengan menggunakan algoritma ant colony optimization (ACO). Pada penelitian tersebut dihasilkan bahwa metode yang digunakan memungkinkan untuk diterapkan pada kasus nyata. Penelitian lain sejenis yang modelnya diterapkan pada kasus nyata adalah penelitian Limiardi dan Cakravastia [2]. Pada penelitian tersebut diperimbangkan beberapa pembatas penting yaitu batasan panjang rute, waktu transportasi, waktu loading dan unloading dengan menggunakan algoritma simulated annealing. Hasil dari penelitian tersebut disimpulkan bahwa beberapa solusi dapat diterapkan di kasus nyata.

Beberapa penelitian SBRP yang telah dijelaskan sebelumnya, mayoritas menggunakan algoritma heuristic yang hasilnya masih bisa dikatakan belum optimal atau penggunaan metode optimisasi yang waktu penyelesaian masalahnya masih relatif terlalu lama. Salah satu penelitian yang membandingkan beberapa metode pemecahan masalah VRP adalah penelitian Li dkk. [10]. Pada penelitian tersebut, dibandingkan beberapa algoritma heuristic terhadap suatu algoritma yaitu algoritma record-to-record travel. Hasil dari penelitian tersebut disimpulkan bahwa algoritma record-torecord travel menghasilkan beberapa solusi baru yang lebih baik, dan waktu penyelesaiannya relatif lebih cepat. Algoritma record-to-record travel merupakan varian dari algoritma simulated annealing yang dapat melakukan uphill moves yang bertujuan untuk mencegah terjebaknya suatu hasil yang minimum secara lokal [11]. Algoritma ini dapat dikembangkan untuk meminimisasi total biaya yang didalamnya terdiri dari beberapa jenis biaya termasuk biaya fixed cost jumlah kendaraan [12].

Berdasarkan hal tersebut, untuk menghasilkan solusi yang lebih baik dari sebelumnya dengan waktu penyelesaian masalah yang lebih cepat, maka penelitian ini bertujuan untuk membangun algoritma dan program perangkat lunak untuk model school bus routing problem (SBRP) yang dapat meminimisasi biaya perjalanan bus dan biaya investasi jumlah kendaraan bus dengan menggunakan algoritma record-torecord travel. Karakteristik dari SBRP yang akan dibangun adalah kendaraan bus yang homogen dan memiliki kapasitas terbatas berawal dari depot, lalu mendatangi titik tujuan berupa halte yang jumlahnya lebih dari satu dimana setiap halte memiliki jumlah penumpang yang deterministik, dan setelah mendatangi halte terakhir maka bus akan mendatangi halte kembali dalam arah yang sebaliknya yang diakhiri ke titik awal depot.

Penerapan model SBRP dan algoritma record-to-record travel ini akan diterapkan pada kasus bus sekolah di Kota Bandung. Saat ini, Pemerintah Kota Bandung sedang menerapkan dan mengevaluasi program bus sekolah gratis yang telah diimplementasi. Berdasarkan data Dinas Pendidikan Kota Bandung [13] bahwa masih terdapat 550 sekolah atau sekitar 44,56\% dari total jumlah sekolah di Kota Bandung yang belum terakomodasi dan belum terjangkau oleh bus sekolah gratis tersebut. Kondisi awal dari rute bus sekolah sekarang ini masih harus dievaluasi, karena rute yang diterapkan masih belum efektif mengingat masih banyak sekolah yang belum dapat dilewati.

Dengan demikian, penelitian ini akan menentukan rute dan jumlah kendaraan yang sesuai dengan jumlah siswa-siswi yang ada di Kota Bandung dimana proses penentuan rute dan jumlah bus akan dikelompokkan berdasarakan wilayah di Kota Bandung. Diharapkan penelitian ini dapat membantu pemerintah sebagai rancangan awal dalam mengevaluasi program bus sekolah gratis di Kota Bandung.

\section{Metode Penelitian}

Pada penelitian ini terdapat beberapa tahapan dari penyelesaian masalah. Tahapan pertama adalah mendeskripsikan masalah yang akan diteliti, lalu melakukan formulasi matematis dari permasalahan yang ada, dan dilanjutkan dengan menerapkan algoritma record-to-record travel beserta program perangkat lunak yang dibangun untuk mengolah data penentuan rute dan jumlah kendaraan bus. Berdasarkan metodologi tersebut, nantinya dilakukan pengujian pada data kasus nyata untuk diusulkan rancangan awal dalam rute dan jumlah kendaraan yang dapat 
diimplementasi. Penelitian ini menggunakan model pengembangan yang berawal dari Moin dkk. [14], dan penambahan dari model Limiardi dan Cakravastia [2]. Algoritma penyelesaian masalah dikembangkan dari algoritma awal Li dkk. [10] dengan menggunakan data objek penelitian dari Limiardi [15].

\subsection{Deskripsi permasalahan}

Pada penelitian ini, permasalahan yang dirancang adalah permasalahan yang terdiri dari sejumlah titik tujuan halte yang harus didatangi, dimana titik awal bus berada di depot dan berakhir di depot, bus memiliki kapasitas terbatas, dan dilakukan pengelompokkan rute berdasarkan wilayah. Penentuan rute ini terdiri dari sejumlah halte yang di setiap halte terdapat penumpang berjumlah deterministik. Pada kasus ini jumlah bus tidak terbatas dan biaya operasional bus terdiri dari biaya perjalanan bus dan biaya investasi bus. Penelitian ini memiliki tujuan untuk meminimumkan biaya perjalanan bus dan biaya investasi bus pada jangka waktu tertentu dengan menggunakan algoritma record-to-record travel.

\subsection{Formulasi matematis}

Formulasi matematis adalah tahapan digambarkannya model penelitian. Pada tahapan ini diformulasikan model penelitian school bus routing problem (SBRP) berdasarkan karakteristik dari penentuan rute dan jumlah kendaraan yang telah dijelaskan sebelumnya. Pada penelitian ini, model Moin dkk. [14] digunakan dengan menghilangkan variabel atau pembatas terkait dengan persediaan, serta diadaptasi pula model Limiardi dan Cakravastia [2] untuk melengkapinya. Berdasarkan penjelasan sebelumnya, permasalahan SBRP beserta notasi dan model matematis yang dirancang adalah sebagai berikut:

$\begin{array}{ll}\frac{\text { Indeks }}{h=\{1,2, \ldots, H\}} & \begin{array}{l}\text { satu set halte yang memiliki } \\ \text { penumpang } h \text { dimana halte } h(h \in\end{array} \\ & H) \\ d=\{0\} & \text { depot }\end{array}$

Parameter

$k$

inv

$t$

$r_{i j}$

$p_{i}$

Kapasitas maksimum per kendaraan bus

Biaya investasi per kendaraan bus (fixed cost)

Biaya perjalanan per jarak perjalanan Jarak dari halte $i$ ke $j$ dimana $r_{i j}=r_{j i}$, untuk setiap $i$ dan $j$

Jumlah penumpang di halte $i$

$\begin{array}{cl}\frac{\text { Variabel }}{x_{i j}} & \begin{array}{l}\text { Penugasan kendaraan bus dari halte } i \\ \text { ke halte } j\end{array} \\ a_{i} & \begin{array}{l}\text { Jumlah penumpang yang diangkut } \\ \text { dari halte } i\end{array} \\ q_{i j} & \begin{array}{l}\text { Jumlah penumpang yang dikirmkan } \\ \text { dari halte } i \text { ke halte } j\end{array}\end{array}$

\section{Fungsi Tujuan:}

$Z=\min \left(t \sum_{\substack{j \in h \cup d \\ j \neq i}} \sum_{i \in h \cup d} r_{i j}\left(x_{i j}\right)+i n v \sum_{i \in h} x_{0 i}\right)$

Fungsi Pembatas:

$$
\begin{aligned}
& \sum_{\substack{i \in h \cup d \\
i \neq j}} q_{i j}+a_{j}=\sum_{\substack{i \in h \\
i \neq j}} q_{j i}, \quad \forall j \in h \\
& \sum_{i \in h} q_{i 0}=\sum_{i \in h} a_{i} \\
& \sum_{\substack{i \in h \cup d \\
i \neq j}} x_{i j}=\sum_{\substack{i \in h \cup d \\
i \neq j}} x_{j i}, \quad \forall j \in h \\
& q_{i j} \leq k, \quad \forall i \in h, \forall j \in h, i \neq j \\
& q_{i} \geq 0, \quad \forall i \in h \\
& x_{i j} \in\{0,1\}, \quad \forall i, j \in h \\
& x_{0 j} \geq 0 \text { and integer, } \forall j \in h \\
& x_{i 0} \geq 0 \text { and integer, } \forall i \in h \\
& x_{i j}=0, \quad i, j \in D \\
& q_{i j} \geq 0, \quad \forall i \in h, \forall j \in h \\
& q_{0 i}=0, \quad \forall i \in h
\end{aligned}
$$

Penjelasan dari formulasi matematis tersebut adalah sebagai berikut: (1) Fungsi tujuan dari penelitian ini yang terdiri dari biaya perjalanan kendaraan bus dan biaya investasi untuk jumlah kendaraan bus yang digunakan; (2) Batasan untuk keseimbangan aliran untuk setiap halte yang dilalui; (3) Jumlah penumpang yang diantarkan secara akumulasi; (4) Batasan dari model untuk keseimbangan jumlah kendaraan yang pergi dan pulang; (5) Kapasitas kendaraan untuk setiap keberangkatan kendaraan bus; (6 sampai dengan 12) Batasan variabel tidak bernilai negatif.

\subsection{Algoritma record-to-record travel pada kasus SBRP}

Algoritma record-to-record travel merupakan algoritma yang dapat digunakan untuk menghindari terjebaknya suatu hasil dalam solusi minimum lokal. Dueck [11] menjelaskan algoritma dari record-to-record travel tersebut, dimana algoritma ini menentukan $X$ sebagai solusi awal dan $X^{\text {, }}$ sebagai alternatif solusi. Solusi terbaik sementara yang didapatkan dijadikan dasar untuk menghitung record deviation.

Pada penelitian Li dkk. [10] besarnya deviasi adalah 1\% dari record terbaik sementara. Jika dalam proses pencarian solusi didapatkan $X^{\prime}$ yang kurang dari record ditambah deviasinya, maka $X^{\prime}$ tersebut menjadi solusi terbarunya. Secara lebih rinci, langkah-langkah dalam menerapkan algoritma record-to-record travel adalah sebagai berikut: 
Inisialisasi:

Set $A=30 ; B=20 ; C=30 ;$ global record $=\sim$; global record deviation $=1 \% \times$ global record

$\underline{\text { Tahap 1: }}$

Pencarian solusi layak menggunakan algoritma least cost insertion; set record $=$ nilai output berdasrakan solusi terbaik sementara; set record deviation $=1 \% \times$ record

Tahap 2:

Set itr $=0$

Do while itr $\leq A$

Set cnt $=0$

Do while cnt $\leq B$

For $i=1$ to $C$

One-point-move; two-point-move; swap-route; twoopt-intra-route;

two-opt-inter-route

If solusi = "tidak layak" then

Go to line "local search"

End if

If solusi = "tidak layak" then

If solusi < record + record deviation then

Set record $=$ current solution

Set record deviation $=1 \% \times$ record

Set cht $=0$

End if

End if

Next $i$

local search:

one-point-move; swap-route; two-opt-intra-route; twoopt-inter-route

(downhill moves)

If solusi = "layak" then

If solusi < record + record deviation then

Set record $=$ current solution

Set deviation $=1 \% \times$ record

Set $\operatorname{cnt}=0$

End if

End if

cnt $=$ cnt +1

Loop

If record $<$ global record + global record deviation

Set global record $=$ record

Set global record deviation $=1 \% \times$ global record

Set itr $=0$

End if

$i t r=i t r+1$

Loop

Output dari solusi global record

Berdasarkan algoritma tersebut, notasi $A$ merupakan jumlah maksimum iterasi yang diperbolehkan ketika global record tidak berubah. Notasi $B$ merupakan jumlah maksimum iterasi yang diperbolehkan ketika local record tidak di berubah. Notasi $C$ menggambarkan jumlah iterasi record-torecord travel dalam melakukan uphill move berdasarkan solusi yang diperoleh. Pada penelitian ini dan eksperimen yang dilakukan untuk menghasilkan solusi terbaik, penelitian ini menggunakan nilai $A$ sebesar $30, B$ sebesar 20, dan $C$ sebesar 30. Penetapan angka tersebut mengikuti eksperimen yang dilakukan oleh Li dkk. [10].

Untuk downhill move digunakan lima local search yaitu one-point-move, two-point-move, swap-route, 2-opt-intra, dan 2-opt inter. Cara kerja dari local search tersebut adalah sebagai berikut: (1) Cara kerja one-point-move adalah dengan mengambil satu node secara random pada suatu rute dan dipindahkan node tersebut ke rute lain yang dapat menghasilkan travel cost paling minimum; (2) Cara kerja dari two-point-move sama dengan istilah 2-0 shift pada penelitian Imran dkk. [16] dimana akan diambil dua node yang berdekatan secara random pada suatu rute tertentu dan akan dipindahkan pada rute lain yang paling meminimumkan travel cost; (3) Cara kerja dari swap-route dilakukan dengan mengambil satu node secara random dan node tersebut dipindahkan ke rute lain secara sistematis dan dicari posisi yang paling meminimumkan travel cost. Prosedur tersebut sama dengan prosedur 1 -1 interchange pada penelitian Imran dkk. [16]; (4) 2-opt-intra dilakukan untuk menghilangkan terjadinya persilangan pada satu rute, sedangkan 2-opt-inter dilakukan untuk menghilangkan persilangan antar rute.

\subsection{Perancangan perangkat lunak pengolahan algoritma record-to-record travel}

Pada penelitian ini, dibangun program perangkat lunak pengolahan algoritma record-to-record travel. Program tersebut berfungsi untuk melakukan pengolahan data input menjadi output berupa rute terbaik dan jumlah kendaraan terbaik yang dapat meminimumkan biaya perjalanan ataupun biaya investasi pengadaan kendaraan bus. Dengan menggunakan program yang dibangun, akan terlihat proses perubahan dari setiap record yang didapatkan dan dapat dilakukan eksperimen secara langsung untuk melakukan percobaan perubahan nilai parameter, maupun pemilihan logika local search yang akan digunakan. Pembangunan program menggunakan Visual Studio 2017 sebagai logika inti dalam pemrosesan data, sedangkan input dan output program menggunakan media Microsoft Office Excel. Contoh user interface dari program perangkat lunak ini dapat dilihat pada Gambar 1.

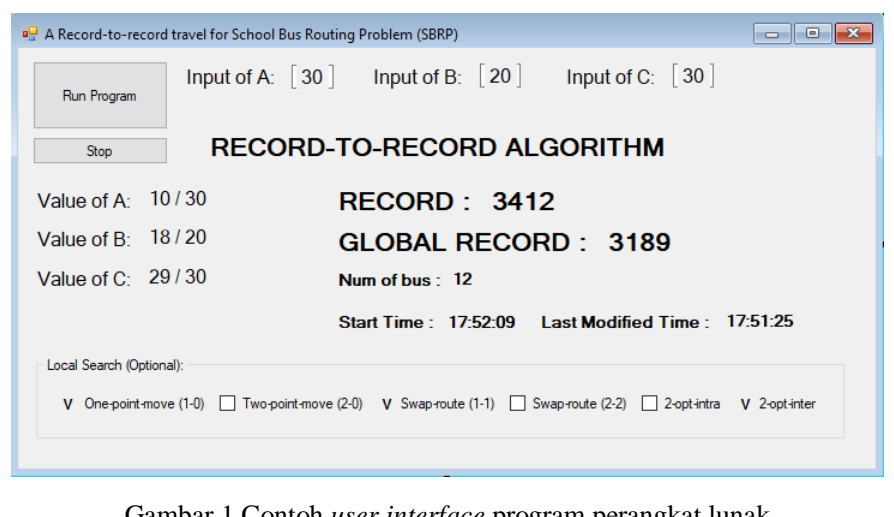

\section{Hasil dan Pembahasan}

Pada penelitian ini proses penginputan data menggunakan data penelitian Limiardi [15] yang melakukan penelitian pada studi kasus bus sekolah Kota Bandung. Data tersebut diobservasi dan divalidasi secara langsung dan 
dibantu dengan perangkat lunak Google Maps API untuk penentuan jarak. Pada penelitian tersebut didapatkan data jarak antar halte dan data parameter lain yang relevan dengan kebutuhan pengolahan data pada penelitian ini. Data lokasi untuk setiap halte beserta jaraknya dapat dilihat pada Tabel 1 sampai dengan 17.

Tabel 1

Lokasi dan kode halte bus wilayah bandung barat

\begin{tabular}{clc}
\hline No. Halte & \multicolumn{1}{c}{ Lokasi Halte } & $\begin{array}{c}\text { Rata-rata } \\
\text { Jumlah } \\
\text { Penumpang }\end{array}$ \\
\hline Halte B01 & Jl. Rajawali Timur (Persimpangan Jl. Rajawali-Garuda) & 24 \\
Halte B02 & Jl. Rajawali Timur (Daerah Rajawali Plaza) & 24 \\
Halte B03 & Jl. Kebonjati (Daerah RS. Kebonjati) & 24 \\
Halte B04 & Jl. Kebonjati (Daerah Bandung Textile Center) & 24 \\
Halte B05 & Jl. Sudirman (Persimpangan Elang) & 24 \\
Halte B06 & Jl. Sudirman (Daerah SDN Bandung Raya Barat) & 24 \\
Halte B07 & Jl. Sudirman (Daerah Pal 3 Cijerah) & 24 \\
Halte B08 & Jl. Rajawali Barat (Daerah Gudang Rajawali) & 24 \\
\hline
\end{tabular}

Tabel 2

Lokasi dan kode halte bus wilayah bandung utara

\begin{tabular}{clc} 
No. Halte & Lokasi Halte & $\begin{array}{c}\text { Rata-rata } \\
\text { Jumlah } \\
\text { Penumpang }\end{array}$ \\
\hline Halte U01 & Jl. Pasteur (Daerah Gd. Panti Asuhan Dana Mulya) & 30 \\
Halte U02 & Jl. Pasteur (Daerah ATM Mandiri RS. Hasan Sadikin) & 30 \\
Halte U03 & Jl. Dr. Djunjunan (Daerah Shuttle Cipaganti Travel) & 30 \\
Halte U04 & Jl. Suria Sumantri (Depan Univ. Kristen Maranatha) & 30 \\
Halte U05 & Jl. Setra Sari (Daerah Shuttle Transline Travel) & 30 \\
Halte U06 & Jl. Sari Manis (Daerah lahan kosong) & 30 \\
Halte U07 & Jl. Pasteur (Daerah PT. Biofarma) & 30 \\
\hline
\end{tabular}

Tabel 3

Lokasi dan kode halte bus wilayah bandung timur

\begin{tabular}{clc}
\hline No. Halte & \multicolumn{1}{c}{ Lokasi Halte } & $\begin{array}{c}\text { Rata-rata } \\
\text { Jumlah } \\
\text { Penumpang }\end{array}$ \\
\hline Halte T01 & Jl. Ahmad Yani (Daerah Pasar Kosambi) & 21 \\
Halte T02 & Jl. Ahmad Yani (Daerah Segitiga Mas) & 21 \\
Halte T03 & Jl. Ahmad Yani (Daerah Dinas Pendidikan) & 21 \\
Halte T04 & Jl. Ahmad Yani (Daerah Sekejati) & 21 \\
Halte T05 & Jl. A.H. Nasution (Daerah Terminal Cicaheum) & 21 \\
Halte T06 & Jl. Ahmda Yani (Daerah Kantor BCA Cicadas) & 21 \\
Halte T07 & Jl. Ibrahim Adjie (Daerah Gedung Matahari) & 21 \\
Halte T08 & Jl. Jakarta (Daerah Persimpangan Kiara Condong) & 21 \\
Halte T09 & Jl. Ahmad Yani (Daerah Stadion Persib) & 21 \\
Halte T10 & Jl. Ahmad Yani (Daerah Rel Kereta Api Kosambi) & 21 \\
Halte T11 & Jl. Ahmad Yani (Daerah Kantor Pos Kosambi) & 21 \\
Halte T12 & Jl. Ahmad Yani (Daerah Gedung Balai Besar Tekstil) & 21 \\
Halte T13 & Jl. Jakarta (Daerah Gedung Agronesia) & 21 \\
Halte T14 & Jl. Jakarta (Daerah Gedung STMIK AMIK) & 21 \\
Halte T15 & Jl. Sukabumi (Daerah Gedung IBCC) & 21 \\
\hline
\end{tabular}

Tabel 4

Lokasi dan kode halte bus wilayah bandung tengah

\begin{tabular}{clc} 
No. Halte & \multicolumn{1}{c}{ Lokasi Halte } & $\begin{array}{c}\text { Rata-rata } \\
\text { Jumlah } \\
\text { Penumpang }\end{array}$ \\
\hline Halte E01 & Jl. Asia Afrika (Daerah Graha Bank Panin) & 14 \\
Halte E02 & Jl. Asia Afrika (Daerah Alun-alun Kota Bandung) & 14 \\
Halte E03 & Jl. PHH. Mustofa (Daerah Surapati Core) & 14 \\
Halte E04 & Jl. PHH Mustofa (Daerah Persimpangan Cimuncang) & 14 \\
Halte E05 & Jl. PHH Mustofa (Daerah Jiwasraya Surapati) & 14 \\
Halte E06 & Jl. PHH Mustofa (Daerah Bilingual School) & 14 \\
Halte E07 & Jl. Surapati (Daerah SDN Cihaurgeulis) & 14 \\
Halte E08 & Jl. Surapati (Daerah YPKP) & 14 \\
Halte E09 & Jl. Surapati (Daerah Kanwil BKN) & 14 \\
Halte E10 & Jl. Surapati (Daerah Kantor Dinas Pertanian) & 14 \\
Halte E11 & Jl. Surapati (Daerah Kantor Pertamina) & 14 \\
Halte E12 & Jl. Surapati (Daerah Kantor Balai Ilmiah ITB) & 14 \\
Halte E13 & Jl. Cikapayang (Daerah ESC) & 14 \\
Halte E14 & Jl. Cikapayang (Daerah Persimpangan Dago) & 14 \\
Halte E15 & Jl. Perintis Kemerdekaan (Indonesia Menggugat) & 14 \\
Halte E16 & Jl. Lembong (Daerah Plaza Telkom) & 14 \\
Halte E17 & Jl. Asia Afrika (Daerah Gedung Keuangan Negara) & 14 \\
\hline
\end{tabular}

Tabel 5

Lokasi dan kode halte bus wilayah bandung selatan

\begin{tabular}{clc} 
No. Halte & \multicolumn{1}{c}{ Lokasi Halte } & $\begin{array}{c}\text { Rata-rata } \\
\text { Jumlah } \\
\text { Penumpang }\end{array}$ \\
\hline Halte S01 & Jl. Leuwipanjang (Daerah Terminal) & 38 \\
Halte S02 & Jl. BKR (Daerah Taman Tegalega) & 38 \\
Halte S03 & Jl. BKR (Daerah Dokkes Polda Jabar) & 38 \\
Halte S04 & Jl. BKR (Daerah Gedung Keuangan CKC) & 38 \\
Halte S05 & Jl. BKR (Daerah Patung Ikan) & 38 \\
Halte S06 & Jl. Pelajar Pejuang 45 (Daerah Persimpangan Seledri) & 38 \\
\hline
\end{tabular}

Tabel 6

Data jarak antar halte wilayah bandung barat (dalam satuan meter)

\begin{tabular}{ccccccccc}
\hline Jarak & $\begin{array}{c}\text { Halte } \\
\text { B01 }\end{array}$ & $\begin{array}{c}\text { Halte } \\
\text { B02 }\end{array}$ & $\begin{array}{c}\text { Halte } \\
\text { B03 }\end{array}$ & $\begin{array}{c}\text { Halte } \\
\text { B04 }\end{array}$ & $\begin{array}{c}\text { Halte } \\
\text { B05 }\end{array}$ & $\begin{array}{c}\text { Halte } \\
\text { B06 }\end{array}$ & $\begin{array}{c}\text { Halte } \\
\text { B07 }\end{array}$ & $\begin{array}{c}\text { Halte } \\
\text { B08 }\end{array}$ \\
\hline Halte B01 & 0 & 1200 & 2000 & 2300 & 2000 & 2500 & 4600 & 2000 \\
Halte B02 & 1200 & 0 & 1400 & 1800 & 3000 & 1900 & 3500 & 4100 \\
Halte B03 & 2000 & 1400 & 0 & 400 & 3200 & 2300 & 3800 & 4400 \\
Halte B04 & 2300 & 1800 & 400 & 0 & 3500 & 2500 & 4100 & 4600 \\
Halte B05 & 2000 & 3000 & 3200 & 3500 & 0 & 11600 & 12100 & 8400 \\
Halte B06 & 2500 & 1900 & 2300 & 2500 & 11600 & 0 & 1500 & 2100 \\
Halte B07 & 4600 & 3500 & 3800 & 4100 & 12100 & 1500 & 0 & 600 \\
Halte B08 & 2000 & 4100 & 4400 & 4600 & 8400 & 2100 & 600 & 0 \\
\hline
\end{tabular}

Tabel 7

Data jarak antar halte wilayah bandung utara (dalam satuan meter)

\begin{tabular}{cccccccc}
\hline Jarak & $\begin{array}{c}\text { Halte } \\
\text { U01 }\end{array}$ & $\begin{array}{c}\text { Halte } \\
\text { U02 }\end{array}$ & $\begin{array}{c}\text { Halte } \\
\text { U03 }\end{array}$ & $\begin{array}{c}\text { Halte } \\
\text { U04 }\end{array}$ & $\begin{array}{c}\text { Halte } \\
\text { U05 }\end{array}$ & $\begin{array}{c}\text { Halte } \\
\text { U06 }\end{array}$ & $\begin{array}{c}\text { Halte } \\
\text { U07 }\end{array}$ \\
\hline Halte U01 & 0 & 500 & 3300 & 3600 & 4700 & 5100 & 400 \\
Halte U02 & 500 & 0 & 3400 & 3700 & 4900 & 5200 & 600 \\
Halte U03 & 3300 & 3400 & 0 & 4600 & 5700 & 6000 & 2200 \\
Halte U04 & 3600 & 3700 & 4600 & 0 & 1100 & 1400 & 5000 \\
Halte U05 & 4700 & 4900 & 5700 & 1100 & 0 & 1300 & 3800 \\
Halte U06 & 5100 & 5200 & 6000 & 1400 & 1300 & 0 & 4800 \\
Halte U07 & 400 & 600 & 2200 & 5000 & 3800 & 4800 & 0 \\
\hline
\end{tabular}

Tabel 9

Data jarak antar halte T01-T08 wilayah bandung timur (dalam satuan meter)

\begin{tabular}{ccccccccc}
\hline Jarak & $\begin{array}{c}\text { Halte } \\
\text { T01 }\end{array}$ & $\begin{array}{c}\text { Halte } \\
\text { T02 }\end{array}$ & $\begin{array}{c}\text { Halte } \\
\text { T03 }\end{array}$ & $\begin{array}{c}\text { Halte } \\
\text { T04 }\end{array}$ & $\begin{array}{c}\text { Halte } \\
\text { T05 }\end{array}$ & $\begin{array}{c}\text { Halte } \\
\text { T06 }\end{array}$ & $\begin{array}{c}\text { Halte } \\
\text { T07 }\end{array}$ & $\begin{array}{c}\text { Halte } \\
\text { T08 }\end{array}$ \\
\hline Halte T01 & 0 & 500 & 800 & 1300 & 4500 & 3200 & 6000 & 2900 \\
Halte T02 & 500 & 0 & 300 & 800 & 3900 & 2700 & 6100 & 2300 \\
Halte T03 & 800 & 300 & 0 & 500 & 3700 & 2400 & 5800 & 2100 \\
Halte T04 & 1300 & 800 & 500 & 0 & 3200 & 1900 & 6000 & 1600 \\
Halte T05 & 4500 & 3900 & 3700 & 3200 & 0 & 1100 & 8100 & 2300 \\
Halte T06 & 3200 & 2700 & 2400 & 1900 & 1100 & 0 & 7000 & 1200 \\
Halte T07 & 6000 & 6100 & 5800 & 6000 & 8100 & 7000 & 0 & 3300 \\
Halte T08 & 2900 & 2300 & 2100 & 1600 & 2300 & 1200 & 3300 & 0 \\
\hline
\end{tabular}

Tabel 10

Data jarak antar halte T01-T08 dengan T09-T15 wilayah bandung timur (dalam satuan meter)

$\begin{array}{cccccccc}\text { Jarak } & \text { Halte T09 Halte T10 } & \text { Halte } & \text { Halte } & \text { Halte } & \text { Halte } & \text { Halte } \\ & & & \text { T11 } & \text { T12 } & \text { T13 } & \text { T14 } & \text { T15 } \\ \text { Halte T01 } & 800 & 300 & 200 & 2300 & 2500 & 2400 & 1600 \\ \text { Halte T02 } & 300 & 2700 & 1900 & 1700 & 2000 & 1800 & 1100 \\ \text { Halte T03 } & 200 & 1400 & 600 & 1500 & 1700 & 1600 & 800 \\ \text { Halte T04 } & 500 & 1900 & 1100 & 1000 & 1200 & 1100 & 1000 \\ \text { Halte T05 } & 4100 & 5400 & 4700 & 4100 & 2700 & 3000 & 3500 \\ \text { Halte T06 } & 3000 & 4400 & 3600 & 3100 & 1600 & 1900 & 2400 \\ \text { Halte T07 } & 5100 & 4200 & 4100 & 5100 & 3700 & 4000 & 4500 \\ \text { Halte T08 } & 1400 & 600 & 1600 & 1800 & 400 & 700 & 1000\end{array}$

Tabel 11

Data jarak antar halte T09-T15 dengan T01-T08 wilayah bandung timur (dalam satuan meter)

\begin{tabular}{ccccccccc}
\hline Jarak & $\begin{array}{c}\text { Halte } \\
\text { T01 }\end{array}$ & $\begin{array}{c}\text { Halte } \\
\text { T02 }\end{array}$ & $\begin{array}{c}\text { Halte } \\
\text { T03 }\end{array}$ & $\begin{array}{c}\text { Halte } \\
\text { T04 }\end{array}$ & $\begin{array}{c}\text { Halte } \\
\text { T05 }\end{array}$ & $\begin{array}{c}\text { Halte } \\
\text { T06 }\end{array}$ & $\begin{array}{c}\text { Halte } \\
\text { T07 }\end{array}$ & $\begin{array}{c}\text { Halte } \\
\text { T08 }\end{array}$ \\
\hline Halte T09 & 800 & 300 & 200 & 500 & 4100 & 3000 & 5100 & 1400 \\
Halte T10 & 300 & 2700 & 1400 & 1900 & 5400 & 4400 & 4200 & 600 \\
Halte T11 & 200 & 1900 & 600 & 1100 & 4700 & 3600 & 4100 & 1600 \\
Halte T12 & 2300 & 1700 & 1500 & 1000 & 4100 & 3100 & 5100 & 1800 \\
Halte T13 & 2500 & 2000 & 1700 & 1200 & 2700 & 1600 & 3700 & 400 \\
Halte T14 & 2400 & 1800 & 1600 & 1100 & 3000 & 1900 & 4000 & 700 \\
Halte T15 & 1600 & 1100 & 800 & 1000 & 3500 & 2400 & 4500 & 1000 \\
\hline
\end{tabular}


Tabel 12

Data jarak antar halte T09-T15 wilayah bandung timur (dalam satuan meter)

\begin{tabular}{cccccccc}
\hline Jarak & $\begin{array}{c}\text { Halte } \\
\text { T09 }\end{array}$ & $\begin{array}{c}\text { Halte } \\
\text { T10 }\end{array}$ & $\begin{array}{c}\text { Halte } \\
\text { T11 }\end{array}$ & $\begin{array}{c}\text { Halte } \\
\text { T12 }\end{array}$ & $\begin{array}{c}\text { Halte } \\
\text { T13 }\end{array}$ & $\begin{array}{c}\text { Halte } \\
\text { T14 }\end{array}$ & $\begin{array}{c}\text { Halte } \\
\text { T15 }\end{array}$ \\
\hline Halte T09 & 0 & 2100 & 3100 & 1400 & 1700 & 1500 & 1200 \\
Halte T10 & 2100 & 0 & 1000 & 2000 & 2200 & 2100 & 1300 \\
Halte T11 & 3100 & 1000 & 0 & 2100 & 2300 & 2200 & 1400 \\
Halte T12 & 1400 & 2000 & 2100 & 0 & 1500 & 1900 & 2300 \\
Halte T13 & 1700 & 2200 & 2300 & 1500 & 0 & 300 & 800 \\
Halte T14 & 1500 & 2100 & 2200 & 1900 & 300 & 0 & 600 \\
Halte T15 & 1200 & 1300 & 1400 & 2300 & 800 & 600 & 0
\end{tabular}

Tabel 13

Data jarak antar halte wilayah bandung selatan (dalam satuan meter)

\begin{tabular}{ccccccc}
\hline Jarak & Halte S01 & Halte S02 & Halte S03 & Halte S04 & Halte S05 & Halte S06 \\
\hline Halte S01 & 0 & 2200 & 2200 & 2500 & 2500 & 4100 \\
Halte S02 & 2200 & 0 & 2900 & 3200 & 3600 & 4800 \\
Halte S03 & 2200 & 2900 & 0 & 1500 & 1100 & 3100 \\
Halte S04 & 2500 & 3200 & 1500 & 0 & 400 & 3800 \\
Halte S05 & 2500 & 3600 & 1100 & 400 & 0 & 3400 \\
Halte S06 & 4100 & 4800 & 3100 & 3800 & 3400 & 0 \\
\hline
\end{tabular}

Tabel 14

Data jarak antar halte E01-E09 wilayah bandung tengah (dalam satuan meter)

\begin{tabular}{cccccccccc}
\hline Jarak & $\begin{array}{c}\text { Halte } \\
\text { E01 }\end{array}$ & $\begin{array}{c}\text { Halte } \\
\text { E02 }\end{array}$ & $\begin{array}{c}\text { Halte } \\
\text { E03 }\end{array}$ & $\begin{array}{c}\text { Halte } \\
\text { E04 }\end{array}$ & $\begin{array}{c}\text { Halte } \\
\text { E05 }\end{array}$ & $\begin{array}{c}\text { Halte } \\
\text { E06 }\end{array}$ & $\begin{array}{c}\text { Halte } \\
\text { E07 }\end{array}$ & $\begin{array}{c}\text { Halte } \\
\text { E08 }\end{array}$ & $\begin{array}{c}\text { Halte } \\
\text { E09 }\end{array}$ \\
\hline Halte E01 & 0 & 3600 & 6000 & 6300 & 5600 & 4800 & 5100 & 4800 & 5000 \\
Halte E02 & 3600 & 0 & 10100 & 9300 & 8500 & 7800 & 8000 & 7000 & 7100 \\
Halte E03 & 6000 & 10100 & 0 & 900 & 1600 & 2400 & 2100 & 3200 & 3300 \\
Halte E04 & 6300 & 9300 & 900 & 0 & 800 & 1500 & 1300 & 2300 & 2500 \\
Halte E05 & 5600 & 8500 & 1600 & 800 & 0 & 700 & 500 & 1500 & 1700 \\
Halte E06 & 4800 & 7800 & 2400 & 1500 & 700 & 0 & 200 & 800 & 1000 \\
Halte E07 & 5100 & 8000 & 2100 & 1300 & 500 & 200 & 0 & 1000 & 1200 \\
Halte E08 & 4800 & 7000 & 3200 & 2300 & 1500 & 800 & 1000 & 0 & 200 \\
Halte E09 & 5000 & 7100 & 3300 & 2500 & 1700 & 1000 & 1200 & 200 & 0 \\
\hline
\end{tabular}

Tabel 15

Data jarak antar halte E01-E09 dengan halte E10-E17 wilayah bandung tengah (dalam satuan meter)

\begin{tabular}{ccccccccc}
\hline Jarak & $\begin{array}{c}\text { Halte } \\
\text { E10 }\end{array}$ & $\begin{array}{c}\text { Halte } \\
\text { E11 }\end{array}$ & $\begin{array}{c}\text { Halte } \\
\text { E12 }\end{array}$ & $\begin{array}{c}\text { Halte } \\
\text { E13 }\end{array}$ & $\begin{array}{c}\text { Halte } \\
\text { E14 }\end{array}$ & $\begin{array}{c}\text { Halte } \\
\text { E15 }\end{array}$ & $\begin{array}{c}\text { Halte } \\
\text { E16 }\end{array}$ & $\begin{array}{c}\text { Halte } \\
\text { E17 }\end{array}$ \\
\hline Halte E01 & 4500 & 5300 & 3900 & 4100 & 3900 & 3000 & 2500 & 500 \\
Halte E02 & 6800 & 8000 & 6200 & 6300 & 4700 & 5900 & 8700 & 1200 \\
Halte E03 & 4400 & 4800 & 4800 & 5000 & 5800 & 6500 & 3600 & 6600 \\
Halte E04 & 3500 & 3900 & 3900 & 4100 & 4900 & 5600 & 3500 & 5700 \\
Halte E05 & 2800 & 3100 & 3100 & 3300 & 4200 & 4800 & 3100 & 8800 \\
Halte E06 & 2000 & 2400 & 2400 & 2600 & 3400 & 4100 & 2800 & 8500 \\
Halte E07 & 2300 & 2600 & 2600 & 2800 & 3700 & 4300 & 3100 & 8800 \\
Halte E08 & 1300 & 1600 & 1600 & 1800 & 2700 & 3300 & 3100 & 7400 \\
Halte E09 & 1200 & 1500 & 1800 & 2000 & 2800 & 3500 & 3300 & 7600 \\
\hline
\end{tabular}

Tabel 16

Data jarak antar halte E10-E16 dengan E01-E09 wilayah bandung tengah (dalam satuan meter)

\begin{tabular}{cccccccccc}
\hline Jarak & $\begin{array}{c}\text { Halte } \\
\text { E01 }\end{array}$ & $\begin{array}{c}\text { Halte } \\
\text { E02 }\end{array}$ & $\begin{array}{c}\text { Halte } \\
\text { E03 }\end{array}$ & $\begin{array}{c}\text { Halte } \\
\text { E04 }\end{array}$ & $\begin{array}{c}\text { Halte } \\
\text { E05 }\end{array}$ & $\begin{array}{c}\text { Halte } \\
\text { E06 }\end{array}$ & $\begin{array}{c}\text { Halte } \\
\text { E07 }\end{array}$ & $\begin{array}{c}\text { Halte } \\
\text { E08 }\end{array}$ & $\begin{array}{c}\text { Halte } \\
\text { E09 }\end{array}$ \\
\hline Halte E10 & 4500 & 6800 & 4400 & 3500 & 2800 & 2000 & 2300 & 1300 & 1200 \\
Halte E11 & 5300 & 8000 & 4800 & 3900 & 3100 & 2400 & 2600 & 1600 & 1500 \\
Halte E12 & 3900 & 6200 & 4800 & 3900 & 3100 & 2400 & 2600 & 1600 & 1800 \\
Halte E13 & 4100 & 6300 & 5000 & 4100 & 3300 & 2600 & 2800 & 1800 & 2000 \\
Halte E14 & 3900 & 4700 & 5800 & 4900 & 4200 & 3400 & 3700 & 2700 & 2800 \\
Halte E15 & 3000 & 5900 & 6500 & 5600 & 4800 & 4100 & 4300 & 3300 & 3500 \\
Halte E16 & 2500 & 8700 & 3600 & 3500 & 3100 & 2800 & 3100 & 3100 & 3300 \\
\hline
\end{tabular}

Tabel 17

Data jarak antar halte E10-E16 wilayah bandung tengah (dalam satuan meter) (lanjutan)

\begin{tabular}{cccccccc}
\hline Jarak & Halte & Halte & Halte & Halte & Halte & Halte & Halte \\
& E10 & E11 & E12 & E13 & E14 & E15 & E16 \\
\hline Halte E10 & 0 & 2100 & 1800 & 2000 & 2900 & 3100 & 3500 \\
Halte E11 & 2100 & 0 & 2200 & 2000 & 3500 & 3700 & 4100 \\
Halte E12 & 1800 & 2200 & 0 & 200 & 1600 & 2300 & 4300 \\
Halte E13 & 2000 & 2000 & 200 & 0 & 200 & 2800 & 2300 \\
Halte E14 & 2900 & 3500 & 1600 & 200 & 0 & 2600 & 2100 \\
Halte E15 & 3100 & 3700 & 2300 & 2800 & 2600 & 0 & 1500 \\
Halte E16 & 3500 & 4100 & 4300 & 2300 & 2100 & 1500 & 0 \\
\hline
\end{tabular}

Selain data pada Tabel 1 sampai dengan Tabel 10, berdasarkan penelitian Limiardi [15] didapatkan data jarak antara depot terhadap setiap halte yang telah dijelaskan sebelumnya. Pada penelitian ini diasumsikan biaya transportasi per km adalah Rp. 700, biaya pengadaan satu bus sekolah adalah 1 miliar rupiah, dan kapasitas per bus yang ditetapkan adalah 70 orang. Asumsi angka-angka tersebut tidak akan mempengaruhi solusi yang diolah, karena pada dasarnya jarak pada rute yang sangat berperan penting dalam menentukan solusi terbaik. Penetapan asumsi tersebut dilakukan agar skala output dapat mendekati kasus nyata yang diamati. Berdasarkan data tersebut digunakan algoritma record-to-record travel untuk mendapatkan solusi terbaik yang paling minimum dari biaya transportasi dan biaya investasi pengadaan bus. Hasil dari pengolahan tersebut dapat dilihat pada Tabel 18 .

Tabel 18

\begin{tabular}{|c|c|c|c|c|}
\hline Wilayah & Rute & $\begin{array}{c}\text { Total } \\
\text { Jarak } \\
\text { Rute }(\mathrm{km})\end{array}$ & $\begin{array}{l}\text { Total } \\
\text { Penumpang } \\
\text { Naik }\end{array}$ & $\begin{array}{l}\text { CPU } \\
\text { time }\end{array}$ \\
\hline Barat & $\begin{array}{l}\text { Depot } \rightarrow \text { Halte B08 } \rightarrow \text { Halte B07 } \rightarrow \\
\text { Halte B06 } \rightarrow \text { Halte B04 } \rightarrow \text { Halte B03 } \\
\rightarrow \text { Halte B02 } \rightarrow \text { Halte B01 } \rightarrow \text { Halte } \\
\text { B05 } \rightarrow \text { Depot }\end{array}$ & 14,7 & 192 orang & 2 detik \\
\hline Utara & $\begin{array}{l}\text { Depot } \rightarrow \text { Halte U03 } \rightarrow \text { Halte U07 } \rightarrow \\
\text { Halte U01 } \rightarrow \text { Halte U02 } \rightarrow \text { Halte U04 } \\
\rightarrow \text { Halte U05 } \rightarrow \text { Halte U06 } \rightarrow \text { Depot }\end{array}$ & 22,8 & 210 orang & 2 detik \\
\hline Timur & $\begin{array}{l}\text { Depot } \rightarrow \text { Halte T10 } \rightarrow \text { Halte T01 } \rightarrow \\
\text { Halte T06 } \rightarrow \text { Halte T05 } \rightarrow \text { Halte T08 } \\
\rightarrow \text { Halte T13 } \rightarrow \text { Halte T14 } \rightarrow \text { Halte } \\
\text { T15 } \rightarrow \text { Halte T03 } \rightarrow \text { Halte T02 } \rightarrow \\
\text { Halte T09 } \rightarrow \text { Halte T12 } \rightarrow \text { Halte T04 } \\
\rightarrow \text { Halte T11 } \rightarrow \text { Halte T07 } \rightarrow \text { Depot }\end{array}$ & 33,5 & 315 orang & 6 detik \\
\hline Selatan & $\begin{array}{l}\text { Depot } \rightarrow \text { Halte S01 } \rightarrow \text { Halte S02 } \rightarrow \\
\text { Halte S04 } \rightarrow \text { Halte S05 } \rightarrow \text { Halte S03 } \\
\rightarrow \text { Halte S06 } \rightarrow \text { Depot }\end{array}$ & 24,7 & 228 orang & 3 detik \\
\hline Tengah & $\begin{array}{l}\text { Depot } \rightarrow \text { Halte E15 } \rightarrow \text { Halte E10 } \rightarrow \\
\text { Halte E11 } \rightarrow \text { Halte E09 } \rightarrow \text { Halte E03 } \\
\rightarrow \text { Halte E04 } \rightarrow \text { Halte E05 } \rightarrow \text { Halte } \\
\text { E07 } \rightarrow \text { Halte E06 } \rightarrow \text { Halte E08 } \rightarrow \\
\text { Halte E12 } \rightarrow \text { Halte E13 } \rightarrow \text { Halte E14 } \\
\rightarrow \text { Halte E16 } \rightarrow \text { Halte E01 } \rightarrow \text { Halte } \\
\text { E17 } \rightarrow \text { Halte E02 } \rightarrow \text { Depot }\end{array}$ & 33,7 & 238 orang & 8 detik \\
\hline
\end{tabular}

Berdasarkan Tabel 18, didapatkan rute, total jarak, total penumpang naik untuk masing-masing wilayah, dan CPU time (lama waktu pengolahan data menggunakan perangkat lunak yag dibangun). Untuk memastikan terakomodirnya jumlah penumpang yang naik, maka total penumpang naik akan dibagi dengan kapasitas bus yang nantinya akan menentukan jumlah bus yang dibutuhkan per wilayah. Selain itu, agar setibanya di halte terakhir bus tidak langsung ke depot melainkan melewati halte dalam arah sebaliknya (sebagai arah pulang sekaligus melewati setiap halte untuk mengakomodir kebutuhan penumpang pada arah sebaliknya) maka didapatkan terdapat dua rute untuk setiap wilayah (pulang dan pergi). Hasil modifikasi rute tersebut dapat dilihat pada Tabel 19.

Berdasarkan Tabel 19, maka didapatkan total biaya perjalanan dan biaya investasi pengadaan kendaraan bus yang dapat dilihat pada Tabel 20. Hasil pada penelitian ini menunjukkan bahwa rute yang dihasilkan dapat menjadi alternatif untuk diimplementasikan pada kondisi sistem nyata di Kota Bandung. Rute yang telah dihasilkan dari algoritma record-to-record travel ini meghasilkan total biaya yang minimum dengan mempertimbangkan biaya transportasi dan biaya fixed cost kendaraan. Pengelompokkan wilayah seperti pada Tabel 20, dapat dijadikan rancangan awal untuk diterapkan pada rute bus sekolah di Kota Bandung. 
Tabel 12

Modifikasi penentuan rute dan jumlah kendaraan bus sekolah kota bandung

\begin{tabular}{|c|c|c|c|c|}
\hline Wilayah & $\begin{array}{l}\text { Kebutuhan } \\
\text { Jumlah Bus }\end{array}$ & $\begin{array}{l}\text { Arah } \\
\text { Rute }\end{array}$ & Rute & $\begin{array}{c}\text { Total } \\
\text { Jarak } \\
\text { Rute } \\
(\mathrm{km})\end{array}$ \\
\hline \multirow[t]{2}{*}{ Barat } & 3 unit & Pergi & $\begin{array}{l}\text { Depot } \rightarrow \text { Halte B08 } \rightarrow \text { Halte B07 } \rightarrow \\
\text { Halte B06 } \rightarrow \text { Halte B04 } \rightarrow \text { Halte B03 } \rightarrow \\
\text { Halte B02 } \rightarrow \text { Halte B01 } \rightarrow \text { Halte B05 }\end{array}$ & 11,4 \\
\hline & & Pulang & $\begin{array}{l}\text { Halte B05 } \rightarrow \text { Halte B01 } \rightarrow \text { Halte B02 } \rightarrow \\
\text { Halte B03 } \rightarrow \text { Halte B04 } \rightarrow \text { Halte B06 } \rightarrow \\
\text { Halte B07 } \rightarrow \text { Halte B08 } \rightarrow \text { Depot }\end{array}$ & 11,4 \\
\hline \multirow[t]{2}{*}{ Utara } & 3 unit & Pergi & $\begin{array}{l}\text { Depot } \rightarrow \text { Halte U03 } \rightarrow \text { Halte U07 } \rightarrow \\
\text { Halte U01 } \rightarrow \text { Halte U02 } \rightarrow \text { Halte U04 } \rightarrow \\
\text { Halte U05 } \rightarrow \text { Halte U06 }\end{array}$ & 14,8 \\
\hline & & Pulang & $\begin{array}{l}\text { Halte U06 } \rightarrow \text { Halte U05 } \rightarrow \text { Halte U04 } \rightarrow \\
\text { Halte U02 } \rightarrow \text { Halte U01 } \rightarrow \text { Halte U07 } \rightarrow \\
\text { Halte U03 } \rightarrow \text { Depot }\end{array}$ & 14,8 \\
\hline \multirow[t]{2}{*}{ Timur } & 5 unit & Pergi & $\begin{array}{l}\text { Depot } \rightarrow \text { Halte T10 } \rightarrow \text { Halte T01 } \rightarrow \\
\text { Halte T06 } \rightarrow \text { Halte T05 } \rightarrow \text { Halte T08 } \rightarrow \\
\text { Halte T13 } \rightarrow \text { Halte T14 } \rightarrow \text { Halte T15 } \rightarrow \\
\text { Halte T03 } \rightarrow \text { Halte T02 } \rightarrow \text { Halte T09 } \rightarrow \\
\text { Halte T12 } \rightarrow \text { Halte T04 } \rightarrow \text { Halte T11 } \rightarrow \\
\text { Halte T07 }\end{array}$ & 23,7 \\
\hline & & Pulang & $\begin{array}{l}\text { Halte T07 } \rightarrow \text { Halte T11 } \rightarrow \text { Halte T04 } \rightarrow \\
\text { Halte T12 } \rightarrow \text { Halte T09 } \rightarrow \text { Halte T02 } \rightarrow \\
\text { Halte T03 } \rightarrow \text { Halte T15 } \rightarrow \text { Halte T14 } \rightarrow \\
\text { Halte T13 } \rightarrow \text { Halte T08 } \rightarrow \text { Halte T05 } \rightarrow \\
\text { Halte T06 } \rightarrow \text { Halte T01 } \rightarrow \text { Halte T10 } \rightarrow \\
\text { Depot }\end{array}$ & 23,7 \\
\hline \multirow[t]{2}{*}{ Selatan } & 4 unit & Pergi & $\begin{array}{l}\text { Depot } \rightarrow \text { Halte S01 } \rightarrow \text { Halte S02 } \rightarrow \\
\text { Halte S04 } \rightarrow \text { Halte S05 } \rightarrow \text { Halte S03 } \rightarrow \\
\text { Halte S06 }\end{array}$ & 16,9 \\
\hline & & Pulang & $\begin{array}{l}\text { Halte S06 } \rightarrow \text { Halte S03 } \rightarrow \text { Halte S05 } \rightarrow \\
\text { Halte S04 } \rightarrow \text { Halte S02 } \rightarrow \text { Halte S01 } \rightarrow \\
\text { Depot }\end{array}$ & 16,9 \\
\hline \multirow[t]{2}{*}{ Tengah } & 4 unit & Pergi & $\begin{array}{l}\text { Depot } \rightarrow \text { Halte E15 } \rightarrow \text { Halte E10 } \rightarrow \\
\text { Halte E11 } \rightarrow \text { Halte E09 } \rightarrow \text { Halte E03 } \rightarrow \\
\text { Halte E04 } \rightarrow \text { Halte E05 } \rightarrow \text { Halte E07 } \rightarrow \\
\text { Halte E06 } \rightarrow \text { Halte E08 } \rightarrow \text { Halte E12 } \rightarrow \\
\text { Halte E13 } \rightarrow \text { Halte E14 } \rightarrow \text { Halte E16 } \rightarrow \\
\text { Halte E01 } \rightarrow \text { Halte E17 } \rightarrow \text { Halte E02 }\end{array}$ & 25,7 \\
\hline & & Pulang & $\begin{array}{l}\text { Halte E02 } \rightarrow \text { Halte E17 } \rightarrow \text { Halte E01 } \rightarrow \\
\text { Halte E16 } \rightarrow \text { Halte E14 } \rightarrow \text { Halte E13 } \rightarrow \\
\text { Halte E12 } \rightarrow \text { Halte E08 } \rightarrow \text { Halte E06 } \rightarrow \\
\text { Halte E07 } \rightarrow \text { Halte E05 } \rightarrow \text { Halte E04 } \rightarrow \\
\text { Halte E03 } \rightarrow \text { Halte E09 } \rightarrow \text { Halte E11 } \rightarrow \\
\text { Halte E10 } \rightarrow \text { Halte E15 } \rightarrow \text { Depot }\end{array}$ & 25,7 \\
\hline
\end{tabular}

Tabel 13

Hasil penentuan rute kendaraan bus sekolah kota bandung

\begin{tabular}{ccccc} 
Wilayah & $\begin{array}{c}\text { Kebutuhan Jumlah } \\
\text { Bus }\end{array}$ & $\begin{array}{c}\text { Total Jarak Rute } \\
(\mathrm{km})\end{array}$ & $\begin{array}{c}\text { Total Biaya } \\
\text { Investasi }\end{array}$ & $\begin{array}{c}\text { Total Biaya } \\
\text { Perjalanan per trip } \\
\text { (pergi-pulang) }\end{array}$ \\
\hline Barat & 3 unit & 22,8 & Rp. 3 miliar & Rp. 15.960 \\
Utara & 3 unit & 29,6 & Rp. 3 miliar & Rp. 20.720 \\
Timur & 5 unit & 47,4 & Rp. 5 miliar & Rp. 33.180 \\
Selatan & 4 unit & 33,8 & Rp. 4 miliar & Rp. 23.660 \\
Tengah & 4 unit & 51,4 & Rp. 4 miliar & Rp. 35.980 \\
\hline
\end{tabular}

\section{Kesimpulan}

Pada penelitian ini diadaptasi algoritma record-to-record travel untuk menyelesaikan school bus routing problem (SBRP) yang bertujuan untuk meminimisasi biaya perjalanan dan biaya investasi pengadaan kendaraan bus. Algoritma record-to-record travel yang dikembangkan dapat menyelesaikan permasalahan SBRP dengan nilai waktu penyelesaian berdasarkan perangkat lunak yang dibangun adalah dibawah 10 detik. Hal tersebut membuktikan bahwa algoritma ini dapat menghasilkan solusi dengan waktu yang cepat. Penelitian ini juga menunjukkan bahwa model dan algoritma tersebut dapat diuji pada kasus nyata seperti kasus bus sekolah di Kota Bandung. Berdasarkan hasil yang didapatkan, dibutuhkan 19 bus sekolah yang tersebar di lima wilayah Bandung (3 Bandung Barat, 3 Bandung Utara, 5 Bandung Timur, 4 Bandung Selatan, dan 4 Bandung Tengah). Hal ini menunjukkan bahwa pengelompokkan bus sekolah berdasarkan wilayah Bandung feasible untuk diimplementasi dengan biaya investasi dan biaya perjalanan per trip yang relatif cukup rendah. Penelitian ini dapat memperkaya pengetahuan dibidang penentuan rute, baik dari pengembangan model maupun pengembangan algoritma untuk penyelesaian masalah. Meskipun penelitian ini telah menghasilkan solusi, masih ada beberapa pengembangan yang harus dilakukan, seperti penentuan nilai parameter pada algoritma record-to-record travel yang lebih sesuai, atau mempertimbangkan waktu tunggu penumpang di halte ataupun waktu tunggu penumpang di dalam bus.

\section{Referensi}

[1] S. Mancini, "The hybrid vehicle routing problem," Transportation Research Part C, vol. 78, pp. 1-12, 2017.

[2] K. Limiardi and A. Cakravastia, "Development model for determination of the route of school bus with length route, riding time, loading-unloading time, and capacitated fleet by using simulated annealing method," in Industrial Engineering and Engineering Management (IEEM), Bali, Indonesia, 2016.

[3] J. Park and B.-I. Kim, "The school bus routing problem: A review," European Journal of Operational Research, vol. 202, pp. 311-319, 2010.

[4] W. A. Ellegood and J. F. Campbell, "Continous approximation models for mixed load school bus routing," Transportation Research Part B: Methodological, vol. 77, pp. 182-198, 2015.

[5] F. M. S. Lima, D. S. Pereira, S. V. Conceicao and N. T. R. Nunes, "A mixed load capacitated rural school bus routing problem with heterogeneous fleet: Algorithms for the Brazilian context," Expert Systems with Applications, vol. 56, pp. 320334, 2016.

[6] S. P. Parvasi, M. Mahmoodjanloo and M. Setak, "A bi-level school bus routing problem with bus stops selection and possibility of demand outsourcing," Applied Soft Computing, vol. 61, pp. 222-238, 2017.

[7] L. Li and Z. Fu, "The school bus routing problem: A case study," Journal of the Operational Research Society, vol. 53, pp. 552-558, 2002.

[8] J. Riera-Ledesma and J.-J. Salazar-Gonzalez, "Solving school bus routing using the multiple vehicle traveling purchaser problem: A branch-and-cut approach," Computers \& Operations Research, vol. 39, pp. 391-404, 2012.

[9] L. Huo, G. Yan, H. Wang and W. Gao, "School bus routing problem based on ant colony optimization algorithm," in ITEC Asia-Pasific, Beijing, China, 2014.

[10] F. Li, B. Golden and E. Wasil, "A record-to-record travel algorithm for solving the heterogeneous fleet vehicle routing problem," Computers \& Operation Research, vol. 34, pp. 27342742, 2007.

[11] G. Dueck, "New optimization heuristics: The great deluge algorithm and the record-to-record travel," Journal of Computational Physics, vol. 104, pp. 86-92, 1993.

[12] F. Ramadhan, A. Imran and A. F. Rizana, "A record-to-record travel algorithm for multi-product and multi-period inventory routing problem," in 5th International Conference on Industrial Engineering and Applications, Singapore, 2018.

[13] Dinas Pendidikan Kota Bandung, "Dinas Pendidikan Kota Bandung," 2016. [Online]. https://disdik.bandung.go.id. [Accessed 8 January 2018].

[14] N. H. Moin, S. Salhi and N. A. B. Aziz, "An efficient hybrid 
genetic algorithm for the multi-product multi-period inventory routing problem," International Journal Production Economics, vol. 133, pp. 334-343, 2011.

[15] K. Limiardi, Pengembangan model penentuan rute bus sekolah dengan mempertimbangkan length route, riding time, loadingunloading time, dan kapasitas bus menggunakan metode simulated annealing, Bandung, Indonesia: Institut Teknologi Bandung, 2017.

[16] A. Imran, S. Salhi and N. A. Wassan, "A variable neighborhood- based heuristic for the heterogeneous fleet vehicle routing problem," European Journal of Operational Research, vol. 197, pp. $509-518,2009$. 